$1-1-1991$

\title{
Obscuring the Importance of Race: The Implication of Making Comparisons Between Racism and Sexism (Or Other -Isms)
}

Stephanie M. Wildman

Santa Clara University School of Law, swildman@scu.edu

Trina Grillo

Follow this and additional works at: http://digitalcommons.law.scu.edu/facpubs

\section{Recommended Citation}

1991 Duke L.J. 397

This Article is brought to you for free and open access by the Faculty Scholarship at Santa Clara Law Digital Commons. It has been accepted for inclusion in Faculty Publications by an authorized administrator of Santa Clara Law Digital Commons. For more information, please contact sculawlibrarian@gmail.com. 


\title{
OBSCURING THE IMPORTANCE OF RACE: THE IMPLICATION OF MAKING COMPARISONS BETWEEN RACISM AND SEXISM (OR OTHER -ISMS)
}

\author{
TRINA GRILlo* \\ AND STEPHANIE M. WILDMAN**
}

\section{Prologue}

Between the time when the Duke Law Journal first solicited this Essay and the present, one of the authors, Trina Grillo, who is of AfroCuban and Italian descent, was diagnosed as having Hodgkin's Disease (a forin of cancer) and has undergone radiation therapy. In talking about this experience she said that "cancer has become the first filter through which I see the world. It used to be race, but now it is cancer. My neighbor just became pregnant, and all I could think was 'How could she get pregnant? What if she gets cancer?" "

Stephanie Wildman, the co-autlior, who is Jewish and white, heard this remark and thought, "I understand how she feels; I worry about getting cancer too. I probably worry about it more than most people, because I an such a worrier."

But Stephanie's worry is not the sane as Trina's. Someone witl cancer can think of nothing else. She cannot watch the World Series without wondering which players have had cancer or who in the players' families might have cancer. This world-view with cancer as a filter is different from just thinking or even worrying often about cancer. The worrier has the privilege of forgetting the worry sometimes, even much of the time. The worry can be turned off. The cancer patient does not have the privilege of truly forgetting about her cancer; even when it is not

Copyright (C) Trina Grillo and Stephanie M. Wildman 1991. We thank the University of San Francisco librarians, especially Lee Ryan, Marian Shostron, and Jean Stefancic, as well as Jessica Armstrong, U.S.F. School of Law Class of 1992, for their research assistance; Phyllis Bursh for nurturing the discussions that led to this paper; and Margaret Russell, Angela Harris, and Jay Folberg for helpful comments. We also thank John Denvir and Catharine Wells for their comments, friendship, and collegiality beyond measure.

- Assistant Professor of Law, University of San Francisco School of Law. J.D., Umiversity of Minnesota, 1974; A.B., Umiversity of California at Berkeley, 1969.

** Professor of Law, Umiversity of San Francisco School of Law. J.D., Stanford University, 1973; A.B., Stanford University, 1970. 
in the forefront of her thoughts, it reinains in the background, coloring her world.

This dialogue about cancer illustrates a principal problem with comparing one's situation to another's. The "analogizer" often believes that her situation is the same as another's. Nothing in the coinparison process challenges this belief, and the analogizer may think that she understands the other's situation in its fullness. The analogy inakes the analogizer forget the difference and allows her to stay focused on her own situation without grappling with the other person's reality.

Yet analogies are necessary tools to teach and to explain, so that we can better understand each others' experiences and realities. We have no other way to understand each others' lives, except by making analogies to events in our own experience. ${ }^{1}$ Thus, the use of analogies provides both the key to greater coinprehension and the danger of false understanding.

\section{INTRODUCTION}

Like cancer, racism/white supremacy is a societal illness. ${ }^{2}$ To people of color, who are the victims of racism/white suprenacy, race is a filter through which they see the world. Whites do not look at the world through this filter of racial awareness, even though they also comprise a race. This privilege to iguore their race gives whites a societal advantage distinct from any advantage received from the existence of discriminatory racisin. Throughout this Essay we use the tern racism/white supreinacy to emphasize the link between the privilege held by whites to ignore their own race and discriminatory racism.

Author bell hooks describes her realization of the connection between these two concepts: "The word racism ceased to be the terin which best expressed for me exploitation of black people and other peo-

1. Angela Harris describes Funes the Memorius, a character of Jorge Luis Borges, who had no ability to categorize and who lived in a world of detail. Borges suggests that Funes was not "capable of thought. To think is to forget differences, geueralize, make abstractious." Harris, Race and Essentialism in Feminist Legal Theory, 42 STAN. L. REv. 581, 582 (1990) (quoting J. L. Borges, LAbyrinths: Selected Stories and Other Writings 66 (D. Yates \& J. Kirby eds. 1964)). Borges might lave added that to think is to analogize.

Harris contrasts Funes with the universal voice of "we the people"-a voice that purports to represent everyone. Id.

2. See D. Bell, ANd We Are Not Saved (1987); Austim, Sapphire Boundl, 1989 WIS. L. REv. 539; Delgado, The Imperial Scholar: Reflections on a Review of Civil Rights Literature, $132 \mathrm{U}$. PA. L. REv. 561 (1984); Freeman, Racism, Rights and the Quest for Equality of Opportunity: $A$ Critical Legal Essay, 23 HARv. C.R.-C.L. L. REV. 295 (1988); Lawrence, The Id, the Ego, and Equal Protection: Reckoning with Unconscious Racism, 39 STAN. L. REV. 317 (1987); Matsuda, Looking to the Bottom: Critical Legal Studies and Reparations, 22 HARV. C.R.-C.L. L. REV. 323 (1987); P. Williams, Alchemical Notes: Reconstructing Ideals from Deconstructed Rights, 22 HARV. C.R.-C.L. L. REv. 401 (1987). 
ple of color in this society and ... I began to understand that the inost useful term was white supremacy." 3 She recounts how liberal whites do not see themselves as prejudiced or interested in domination through coercion, yet "they cannot recognize the ways their actions support and affirm the very structure of racist domination and oppression that they profess to wish to see eradicated."4 For these reasons, "white supremacy" is an important term, descriptive of American social reality. In this Essay, we link the term racism to white supremacy as a reminder that the perpetuation of white supreinacy is racist. 5

This Essay originated when the authors noticed that several identifiable phenomena occurred without fail, in any racially mixed group, ${ }^{6}$ whenever sex discrimination was analogized (implicitly or explicitly) to race discrimination. Repeatedly, at the annual meeting of the Association of American Law Sclools (AALS), at meetings of feminist legal scholars, in classes on Sex Discrimination and the Law, and in law school women's caucus ineetings, the pattern was the same. In each settimg, although the analogy was made for the purpose of illumination, to explain sexism and sex discrimination, another unintended result ensued-the perpetuation of racism/white suprennacy.

When a speaker compared sexism and racism, the significancc of race was marginalized and obscured, and the different role that race plays in the lives of people of color and of whites was overlooked. The concerns of whites becalne the focus of discussion, even when the conversation lad been supposedly centered on race discrimination. Essentialist presumptions became implicit in the discussion; it would be assumed, for example, that all women are white and all African-Americans are men. ${ }^{7}$ Finally, people with hittle experience in thinking about racism/white supremacy, but who had a liard-won understanding of the allegedly analogous oppression (sexisin or some otler -ism), assumed that they comprehended the experience of people of color and thus had standing to speak on their behalf.

3. B. HOOKS, overcoming white supremacy: a comment, in TALKING BACK: THINKING FEMINIST, THINKING BLACK 112 (1989).

4. Id. at 113.

5. Although the perpetuation of white supremacy is racist, we do not beheve that most whites want to be racist or white supremacist.

6. The racially-mixed groups to which we refer are predominantly white.

7. Essentialist thinking reduces a complex being to one "essential characteristic." For discussions of essentialism, see ALL THE WOMEN ARE WHTtE, AII THE BLACKS ARE MEN, BUT SOME OF US ARE BRAVE: BLACK WOMEN's STUDIES (G. Hull, P. Scott \& B. Smith eds. 1982) (a collection of essays on black women's studies) [heremafter BUT SOME OF US ARE BRAVE]; E. SPELMAN, Inessential Woman: Problems of Exclusion in Feminist Thought (1988); Crenshaw, Demarginalizing the Intersection of Race and Sex: A Black Feminist Critique of Antidiscrimination Doctrine, Feminist Theory and Antiracist Politics, 1989 U. CHI. LEGAL F. 139; Harris, supra note 1. 
No matter how carefully a setting was structured to address the question of racism/white supremacy, these problems always arose. Each of the authors has unwittingly participated in creatimg these problems on many occasions, yet when we have tried to avoid them, we have found ourselves accused of making others uncomfortable. ${ }^{8}$ Even after we had identified these patterns, we found ourselves watching in amazement as they appeared agam and again, and we were unable to keep ourselves from contributing to them.

We began to question why this pattern persisted. We concluded that these phenomena have much to do with the dangers inherent im what had previously seemed to us to be a creative and solidarity-producing process-analogizing sex discrimination to race discrimination. These dangers were obscured by the promise that to discuss and compare oppressions might lead to coalition-building and understanding. On an individual psychological level, the way we empathize with and understand others is by comparing their situations with some aspects of our own. As Lymr Henderson explams:

Analogizing, or drawing upon one's own experience to understand another's feelings or experiences, is a part of relating to another, if for no other reason than that no one has exactly the same experiences as anyone else. But this is an obvious point. The less obvious point is that it is possible to draw on one's own similar experiences to understand another. One could otherwise not enpathize with another's grief at losing a parent at all if one could not draw on one's own experiences of loss ....9

Roberto Unger describes the importance of analogy in the human thought process as follows:

We compare the issues about which we have the greatest certainty with those that baffle us more. The decision to liken one instance to another, or to distinguish them, turns on a judgment of what differences and similarities are most significant to the moral behiefs at stake. ${ }^{10}$

Thus, analogies deepen our consciousness and permit us to progress in our thinking. Analogies are an important, perhaps imdispensable, tool in imdividual moral reasoning.

This Essay is our effort to begin to understand how the process of comparing oppressions creates the phenomena that consolidate racism/ white supremacy. We beheve that the participants in the meetings we have described, who used analogies between sexism and racism, were well-imtentioned. They were people with anti-racist politics and no desire

8. See, e.g., A. LORDE, The Uses of Anger, in SISTER OUTSIDER 128 (1984) ("Mainstream communication does not want women, particularly white women, responding to racism.").

9. Henderson, Legality and Empathy, 85 MrCH. L. REv. 1574, 1581 n.37 (1987).

10. R. UNGeR, KNOWLEDGE AND Politics 258 (1975). 
to perpetuate racism/white supremacy. But even well-mtentioned people may act unwittingly to maintain racism/white supremacy. ${ }^{11}$

Although the central focus of this Essay is the analogy between sexism and racism, we also discuss comparisons with other "-isins," including anti-Semitism, heterosexism, and the treatment of the physicallychallenged. The use of these coinparisons further illuminates the analogy problem because the issues surrounding the use of analogies exist for these -isms as well.

\section{How the Sex/Race Analogy Perpetuates Patterns of RACIAL DOMINATION}

Comparing sexism to racism perpetuates patterns of racial domination by marginalizing and obscuring the different roles that race plays in the hives of people of color and of whites. The comparison minimizes the impact of racism, rendering it an insignificant phenomenon-one of a laundry hist of -isms or oppressions that society must suffer. This marginalization and obfuscation is evident in three recognizable patterns: (1) the taking back of center-stage from people of color, even in discussions of racism, so that white issues remain or become central in the dialogue; (2) the fostering of essentialism, so that women and people of color are implicitly viewed as belonging to mutually exclusive categories, rendering women of color invisible; and (3) tlre appropriation of pain or the denial of its existence tliat results when whites wlio have compared otlier oppressions to race discrimination believe that they understand the experience of racism.

\section{A. Taking Back the Center}

White supremacy creates in whites the expectation that issues of concern to them will be central in every discourse. Analogies serve to perpetuate this expectation of centrality. The center-stage problem occurs because dominant group members are already accustomed to being on center-stage. They liave been treated that way by society; it feels natural, comfortable, and in the order of things.

The harms of discrimination include not only the easily identified disadvantages of the victims (sucli as exclusion from liousing and jobs) and the stigina imposed by the dominant culture, but also the advantages given to those who are not its victims. The white, male, heterosexual societal norm is privileged in sucli a way that its privilege is rendered invisible. As Kimberlé Crenshaw explained:

11. For an excellent discussion of unconscious racism, see Lawrence, supra note 2. 
According to the dominant view, a discriminator treats all people within a race or sex category similarly. Any significant experiential or statistical variation within this group suggests ... that the group is not being discriminated against .... Race and sex, inoreover, becoine significant only when they operate to explicitly disadvantage the victims; because the privileging of whiteness or maleness is implicit, it is generally not perceived at all. ${ }^{12}$

Because whiteness is the norm, it is easy to forget that it is not the only perspective. Thus, members of dominant groups assume that their perceptions are the pertinent perceptions, that their problems are the problems that need to be addressed, and that im discourse they should be the speaker rather than the histener. ${ }^{13}$ Part of being a member of a privileged group is being the center and the subject of all mquiry in which people of color or other non-privileged groups are the objects. ${ }^{14}$

So strong is this expectation of holding center-stage that even when a time and place are specifically designated for inembers of a non-privileged group to be central, members of the dominant group will often atteinpt to take back the pivotal focus. They are stealing the center ${ }^{15}$ usually with a complete lack of self-consciousness. ${ }^{16}$

This phenomenon occurred at the annual meeting of Law and Society, where three scholars, all people of color, were invited to speak to the plenary session about how umiversities might become truly multicultural. Even before the dialogne began, the views of many meinbers of the organization were apparent by their presence or absence at the session. The audience included nearly every person of color who was attending the meeting, yet many whites chose not to attend.

When people who are not regarded as entitled to the center move into it, however briefly, they are viewed as usurpers. One reaction of the group teinporarily deprived of the center is to inake sure that nothing remains for the perceived usurpers to be in the center of. Thus, the whites who did not attend the plenary session, but who would have attended had there been more traditional (i.e., white) speakers, did so in part because they were exercising their privilege not to think in terms of

12. Crenshaw, supra note 7 , at $150-51$.

13. See Wildman, The Question of Silence: Techniques to Ensure Full Class Participation, 38 J. LEGAL EDUC. 147, 149-50 (1988).

14. See HoOKs, supra note 3 , at 43 (discussing hberation struggles initiated when people seen as objects "assert that they are subjects").

15. Parents of young children who try to have a telephone conversation will easily recognize this phenoinenon. At the sound of the parent's voice on the phone, the child materializes from the far reaches of the house to demand attention.

16. For an interesting discussion of how law contributes to our vision of reality and our selfconsciousness, see Reich, Law and Consciousness, 10 CARDozo L. REV. 77 (1988). 
race, and in part because they resented the "out groups" having the center.

Another tactic used by the dominant group is to steal back the center, using guerilla tactics where necessary. For example, during a talk devoted to the integration of multicultural materials into the core curriculum, a white man got up from the front row and walked noisily to the rear of the room. He then paced the room in a distracting fashion and finally returned to his seat. During the question period he was the first to rise, leaping to his feet to ask a lengthy, rambling, question about how multicultural materials could be added to university curricula without disturbing the "canon"--the exact subjeet of the talk he had just, apparently, not listened to.

The speaker answered politely and explaimed how he had assigned a Navajo creation myth to accompany St. Augustine, which highlighted Augustine's paganism and resulted in each reading enriching the otler. $\mathrm{He}$ reframed, however, from calling attention to the questioner's rude behavior during the meeting, to his asking tlie already-answered question, or to his presuniption that the material the questioner saw as most relevant to his own life was central and "canonized," while all other reading was peripheral, and, hence, dispensable.

Analogies offer protection for the traditional center. At another gatlering of law professors-the annual meeting of the American Association of Law Schools-issues of racism, sexism, and lomophobia were the focus of the plenary session for the first time in the organization's history. Agaim at this session, the nuniber of white males present was far fewer than would ordinarily attend sucli a session. After moving presentations by an African-American wornan, an Hispanic man, and a gay white man who each opened tlieir hearts on these subjects, a question and dialogue period began.

The first speaker to rise was a white woman, who, after saying that she did not mean to cliange the topic, said that she wanted to discuss another sort of oppression-that of law professors im the less elite scliools. As professors from what is perceived by some as a less-tlianehite school, we agree that the topic is important and it would have interested us at anotlier time, on anotlier day. But this questioner had succceded in depriving the otller issues of time devoted (after much struggle) specifically to them, and turned the spothight once again onto her own concerns. Slie did this, we believe, not out of malice, but because slie too had become a victim of analogical thinking.

The problem of taking back the center exists apart from the issue of analogies; it will be with us as long as any group expects, and is led to expeet, to be constantly the center of attention. But the use of analogies 
exacerbates this problem, for once an analogy is taken to heart, it seems to the center-stealer that she is not stealing the center, but rather is contimuing the discussion on the same topic, and one that she knows well. ${ }^{17}$ So when the format of the program imphicitly analogized gender and sexual preference to race, the center-stealer was encouraged to think "why not go further to another perceived oppression?"

When socially-subordmated groups are lumped together, oppression begins to look like a uniform problem and one may neglect the varying and complex contexts of the different groups being addressed. If oppression is all the same, then we are all equally able to discuss each oppression, and there is no felt need for us to histen to and learn froin other socially-subordinated groups.

\section{B. Fostering Essentialism}

Essentialism is implicit in analogies betwcen sex and race. Angela Harris explains gender essentialism as "[t]he notion that there is a monohthic 'women's experience' that can be described independent of other facets of experience like race, class, and sexual orientation ...."18 She continues: "A corollary to gender essentialism is 'racial essentialisin'the behief that there is a monohthic 'Black Experience,' or 'Chicano Experience." "19

To analogize gender to race, one must assume that each is a distinct category; the impact of which can be neatly separated, one froin the other. ${ }^{20}$ The essentialist critique shows that this division is not possible. Whenever it is attempted, the experience of women of color, who are at the intersection of these categories and cannot divide themselves to compare their own experiences, is rendered imvisible. Analogizing sex discrimination to race discrimination makes it seem that all the women are

17. In one sex discrimination class, the assigned reading consisted of three articles by black woinen. In the discussion, inany white women focused on sexisin and how they understood the women of color by seeing the sexism in their own lives. The use of analogy allowed the white women to avoid the implications of white privilege and made the wounen of color feel that their distinct experience was rendered invisible.

Additionally, for the first time that semester, many members of the class had evidently not done the reading. Although the end of the semester was near, was this a guerilla tactic to retake the center or simply a lack of interest by the dommant group in the perceptions of the non-dominant group (another form of manifestimg entitlement to centrality)?

18. Harris, supra note 1, at 588.

19. Id.

20. See SPELMAN, supra note 7 (criticizing the way that gender essentialism ignores or effaces the experiences of women perceived as different from the white norm). For further discussion of the essentialist critique, see Crenshaw, supra note 7; and Harris, supra note 1; see also Delgado \& Stefancic, Why Do We Tell the Same Stories? 42 StAN. L. REv. 207 (1989) (describing the role of categorization, broad or narrow, in channeling thought). 
white and all the men are African-American. ${ }^{21}$ The experiential reality of women of color disappears. "Moreover, feminist essentialism represents not just an imsult to black women, but a broken promise-the promise to listen to women's stories, the promise of feminist method."22

Many whites think tliat people of color are obsessed with race and find it hard to understand the emotional and intellectual energy that people of color devote to tlie subject. But whites are privileged in that they do not have to think about race, even tliough they have one. White supremacy makes whiteness the normative model. Being the norm allows whites to ignore race, except when they perceive race (usually someone else's) as intruding upon their lives. ${ }^{23}$

\section{The Appropriation of Pain or the Rejection of Its Existence}

Part of the privilege of whiteness is the freedom not to think about race. Whites need to reject this privilege and to recognize and speak about tlieir role im the racial hierarchy. Yet whites cannot speak validly for people of color, but only about their own experiences as whites. Comparing other oppressions to race gives whites a false sense that they fully understand the experience of people of color. Sometimes the profession of understanding by members of a privileged group may even be a guise for a rejection of the existence of the pain of the unprivileged. For people of color, listening to whites who purport to represent the experience of racism feels like an appropriation of the pain of living in a world of racism/white supremacy.

The privileging of some groups in society over otliers is a fact of contemporary American life. ${ }^{24}$ This privileging is identifiable in the ordering of societal power between whites and people of color; men and women; heterosexuals and gays and lesbians; and able-bodied and pliysi-

21. Hull \& Smith, Introduction: The Politics of Black Women's Studies, in BuT SOME OF Us ARE BRAVE, supra note 7, at $\mathrm{xx}$.

22. Harris, supra note 1 , at 601 .

23. Angela Harris writes: "In this society, it is only white people who have the luxury of 'having no color'; only white people have beeu able to imagine that sexisin and racisin are separate experiences." Id. at 604 . Harris describes a meeting of woinen law professors who were asked to pick out two or three words to describe who they were. Harris reports that none of the white women mentioned race; all of the woinen of color did. Id.

24. See, e.g., Wildinan, Integration in the 1980s. The Dream of Diversity and the Cycle of Exclusion, 64 TULANE L. REv. 1625, 1629 (1990) (discussing the privileging of white males in the legal profession). 
cally-challenged people. ${ }^{25}$ This societal ordering is clear to children as early as kindergarten. 26

Judy Scales-Trent has written about her own experience as an African-American woinan, of "being black and looking white," a woinan who thereby inhabits both sides of the privilege dichotoiny. ${ }^{27}$ As one who was used to being on the unprivileged side of the race dichotoiny in soine aspects of her life, she discusses how the privilege of being ablebodied allowed her to ignore the pain of an unprivileged woinan in a wheelchair, humiliated in secking access to a meeting place. ${ }^{28}$ She realized that her role as the privileged one in that pairing likened her to whites in the racial pairing. The analogy helped her see the role of privilege and how it affects us, presenting another exainple of how coinparisons are useful for promoting understanding. But this imsight did not lead her to assume that she could speak for those who are physically challenged; rather, she realized that she needed to histen more carefully.

Not all people who learn about others' oppressions through analogy are blessed with an imcreased commitment to histening. White people who grasp an analogy between an oppression they have suffered and race discrimination may think that they understand the phenomenon of racism/white supremacy in all its aspects. They nnay beheve that their opinions and judgments about race are as cogent as those of victinis of racism. In this circumstance, soinething approximating a lack of standmg to speak exists because the insight gained by personal experience cannot easily be duphicated-certainly not without careful study of the oppression under scrutiny. ${ }^{29}$ The power of coinparisons undernines this

25. See Wildman, The Classroom Climate: Encouraging Student Involvement, 4 BerKelEY WOMEN'S L.J. 326 (1989-90).

26. See F. Kendall, Diversity in the Classroom: A Multicultural Approach to THE EDUCATION OF YOUNG CHILDREN 19-21 (1983) (describing the development of racial awareness and racial attitudes in young children). Although the prevalent view would state that children are "oblivious to differences in color or culture," id. at 19, children's racial awareness and their positive and negative feelings about race appear by age three or four. Id. at 20.

27. Scales-Trent, Commonalities: On Being Black and White, Different and the Same, 2 YALE J.L. \& FEMINISM 305, 305 (1990).

28. Id. at 322-24.

29. Standing to talk about the harm of racism has received attention in legal academic circles recently. Randall Kennedy argues that people of color should not receive particular legitimacy within the academy, sinnply because they are of color. R. Kennedy, Racial Critiques of Legal Academia, 102 HARV. L. REv. 1745 (1989). Kennedy takes issue with the writings of several scholars of color whom he characterizes as proponents of a "racial distinctiveness thesis," which holds that the perspective of a scholar who has experienced racial oppression is different and valuable because of this awareness. Id. at 1746.

Replying to Kennedy, Leslie Espinoza argues that it is precisely Kennedy's standing as a person of color that gives special voice and power to his message: "Because Kennedy is black, his article relieves those in power in legal academia of concern about the merits of race-focused critiques of their stewardship, and it does so on the 'objective' basis of scholarly methodology." Espinoza, 
lack of standing, because by emphasizing similarity and obscuring difference, it permits the speaker implicitly to demonstrate authority about both forms of oppression. If we are members of the privileged halves of the social pairs, then what we say about the dichotomy will be listened to by the dominant culture. ${ }^{30}$ Thus, when we employ analogies to teach and to show oppression in a particular situation, we should be careful that in borrowing the acknowledged and clear oppression, we do not neutralize it, or make it appear fungible with the oppression under discussion.

The use of analogies by whites allows them to focus on their own experience and to avoid working on understanding racism/white supremacy. Even whites who wish to end discrimination want people of color to teach them about race and are often unwilling to use their personal resources to explore this dangerous subject. As bell hooks lias written:

In talking about race and gender recently, the question most often asked by white women has to do with white women's response to black women or women of color insisting that they are not willing to teach them about their racism-to show the way. They want to know: What should a white person do who is attempting to resist racism? It is problematic to assert that black people and other people of color who are simcerely committed to struggling against white supremacy should be unwilling to help or teach white people. ${ }^{31}$

She says that many people of color have responded with an unwillingness to teach whites about combatting racism/white supremacy because it often seems that white people are asking people of color to do all the work. She concludes, however, that "[i]t is our collective responsibihity as people of color and as white people who are committed to ending white supremacy to help one another." 32

Author hooks encourages people of color to continue to struggle with whites about racism. To whites, the need for such encouragement may seem surprising, because many whites might ask, "How can we work on racism by ourselves, without people of color?" Listening to the

Masks and Other Disguises: Exposing Legal Academia, 103 HARV. L. REV. 1878 (1990). Espinoza discusses the "hidden barriers," id. at 1879, to participation by people of color in the legal acadeiny; these "[s]ubtle barriers create a cycle of exclusion." Id. at 1881. The doininant discourse within the legal academy provides an identity to the privileged group as well as "a form of shared reality in which its own superior position is seen as natural." Delgado, Storytelling for Oppositionists and Others: A Plea for Narrative, 87 Mich. L. REv. 2411, 2412 (1989).

30. For a "limited seleetion" of the work of scholars of color about race and civil rights who have not been widely cited, see Delgado, supra note 2. See also Espinoza, supra note 29, at 1880-81 n.13.

31. Hooks, supra note 3 , at 117.

32. Id. at 118 . 
reality of people of color is very important for learning about the oppression of racism/white supremacy. But whites need to examine their (our) own role $\mathrm{m}$ benefiting from that social construct. When white women analogize sexism to racism to emphasize the disadvantages imposed by the culture upon women, they (we) must also remember the privileging granted by that same society to whites.

Trying to educate whites about race is a grcat risk for people of color. They risk not only that whites will not care and will prefer to perpetuate the status quo, but also that even caring whites will not hear or understand the pain of racism. Talking about racism/white supremacy is painful for whites as well, but in a different way. Whites must confront their role as oppressors, or at least as beneficiaries of the racial oppression of others, in a race-based hierarchy. The pain of oppression must be communicated to the dominant group if there is to be any understanding of racism/white supremacy. This act of sharing, however, contains the risk that the pain of oppression will be appropriated by the dominant group for its own purpose.

This appropriation of pain occurred during a Critical Legal Studies summer cainp devoted to a discussion of gender and race. A Native Canadian woman realized that her life experience as a dispossessed person bcaring the sting of racism/white supremacy had been dissected by the group and that no one was really hcaring or responding to her paim, and stated:

I had gone away for this conference quite settled with having to deal with racism, pure and simple. But, I was not ready to have my pain appropriated. I ain pretty possessive about my pain. It is my pain. I worked hard for it. Some days it is all I have. Some days it is the only thing I can feel. Do not try to take that away from me too. ${ }^{33}$

This woman protested the appropriation of her pain by others who would objectify and minimize it. ${ }^{34}$

Many people at the summer camp seemed concerned that their own pain might be overlooked. ${ }^{35}$ We share a primal, and not unreasonable,

33. Monture, Ka-Nin-Geh-Heh-Gah-E-Sa-Nonh-Yah-Gah, 2 CANADIAN J. WOMEN \& L./REvue JuRidiQue de LA Feminine et Le Drort 159, 163 (July 1988).

34. At a later group discussion, these comments about pain were retold by a white woman who was defending the use of personal experience at the summer camp. A white male participant responded, "The pain of minority people is like television, we can turn it on and off as we want to." Id. at 167 .

Monture writes: "Did the man intend to belittle my pain and my life? Did he know how deeply he had clawed into my essence? Did that woman intend to appropriate my pain for her own use, stealing my very existence, as so many other White, well-meaning, middle and upper class feminists have done?" Id.

35. At one poimt the camp participants discussed untenured professors as an oppressed group. During the next day's discussion a woman professor of color shared a dream she had had the previ- 
fear that if we open ourselves enough to comprehend another's pain, we will lose our right to feel our own. especially if ours cannot compete in the pain sweepstakes. How can oue compare the problems of, for exainple, an untenured, white male professor with those of undernourished Native American children, whose people have been the victims of genocide ${ }^{36}$ And yet, as long as we are human, the first filter through which we look will be the one constructed by the events of our individual hives.

The use of analogy exacerbates this natural desire to have our own strnggles receive recognition. For if we can convince ourselves that another's experience is "just like" ours, we are then exempt from having fully to comprehend that experience. ${ }^{37}$

When I [Trina] was in law school, the women in the Women's Caucus, all white except for me, insisted that sexism was "worse than" racism. I disagreed (as one who should know) and pointed out that women of color generally find racisin harder to deal with than sexisin. The fainous statement to the contrary by Shirley Chisholm ${ }^{38}$ was raised, and the argument ended.

The interesting part of this interchange was that if these women could show that sexism was worse than racism, then ("hallelujah!") they beheved their reason to worry about racism had vainshed. The women thought that they understood racism by virtue of their experiences with sexism and that they were working on something more important.

The use of the sex/race analogy gave the analogizers permission to make invisible and unimportant experiences that were central to the lives of others. This resulted in a demal of the existence of pain. Thus, both

ous night, in which there was a pain competition, with comparative pain being measured by large thermometers.

36. It is hard to feel the pain of others, to realize how many horrors have been perpetrated, how nuany terrible things have happened, and to realize the relative privilege (anyone able to read this Essay is more than relatively privileged) that makes one exempt from some of these horrors.

Another cancer example illustrates how people nust block out the pain that surrounds them in order to survive. The doctors and technologists in the radiation therapy department are all mice, friendly people. No one is unkind. But every day I [Trina] an stunned by how they fail to see or acknowledge the vast anounts of pain around them.

Not only do they not notice this pain, but they may take active steps to discount it if they do see it. One oncology nurse, speaking to a patient undergoing chemotherapy and experiencing nausea, said, "It's just the same as nuorning sickness, don't make such a big deal about it." By naking the comparison the nurse is implicitly saying, "What you are experiencing is only what I have experienced, and therefore I do not nced to listen to your story."

37. For the listener, when the speaker presumes to understand, but does not, the emotion generated is rage. For a discussion of women of color and anger in the context of mediation, see Grillo, The Mediation Alternative: Process Dangers for Women, 100 YALE L.J. 1545 (1991).

38. Chisloln, Racism and Anti-Feminism, I THE BlACK SCHOLAR 40 (1970). Chisholm, who describes this country as "both racist and anti-feminist," id. at 40 , says, "The harshest discrimination that I lave encountered in the political arena is anti-feminism." Id. at 43. 
the appropriation of pain and the denial of its existence are fostered by conuparing oppressions. ${ }^{39}$

\section{CONCLUSION}

Given the problenis that analogies create and perpetuate, should we ever use then!? Analogies can be helpful. They are part of legal discourse, as well as common conversation. Consciousness raisnig nay be the beginning of knowledge. Starting with ourselves is important, and analogies may enable us to understand the oppression of another in a way we could not without making the coniparison. Instead of drawing false inferences of similarities from analogies, it is important for whites to talk about white supreniacy, rather than leaving all the work for people of color. Questions reniain regardinig whether analogies to race can be used, particularly in legal argument, without reinforcing racisn1/white supremacy. There are no simple answers to this thorny problen1. We will have to continue to struggle with it, and accept that our progress will be slow and tentative. We offer two preliminary suggestions, each with its own pitfalls, to illustrate the sort of changes we might make in daily discourse to guide the use of comparisons: recognition tine and coalition work.

Recognition time is time devoted exclusively to examining one oppression. It may mitigate one problenı created by niaking analogies to race-the nuarginalizing and obscuring of racisnı/white supreinacy. Recogintion time acknowledges both the need to honor the pain of those oppressed by other -isnis, each in their turn, and the need to allow the oppression benig focused upon to reniain center-stage.

Creating recognition time niay not be an easy process, and raises probleıns of its own. An African-American wonian law professor who teaches a semmar on women of color and the law has said that she finds it difficult to focus the students on gender issues; they want to stay with race. Why might this happen? If the first filter through which one looks at the world is not acknowledged, one cannot nove on to other, perhaps even equally important, filters. When we combine several sociallysubordiniated groups into one discussion (as analogies implicitly do) and do not identify a distinct tine to recognize one specific oppression or another, other than to use then as reference points for an analogy, we create an inability to focus on any one of them. This does not niean that the oppressions are unrelated, but rather, that they must be studied sepa-

39. Moreover, this attitude creates problems for those of us who have both battles to fightbattles that are not separable in our personal lives. See supra notes 18-23 and accompanying text. 
rately as well as together. To allow these separate and focused recognition times imight relax people.

The danger of recognition time, if defined too narrowly, is that it would encourage essentialism. Essentialism could be avoided if each oppression were examined in its fullness. In discussing sexisin, for example, we need to recognize that every woman is affected by racism/white supremacy in one way or another. Within the context of a full discussion of sexual oppression, one would necessarily talk about the effect of race. ${ }^{40}$

For people facing oppression, working together or coalition building is also critically important. In a racism class at one law school, I [Stephanie] was asked to team-teach a class on Jewish Racism and AfricanAmerican Anti-Sernitism. The Jewish students felt that anti-semitic remarks had been inade throughout the semester and that neither the law school's curriculuin nor its culture addressed issues of anti-semitisin. The students of color felt that during the one course in the curriculum designed to address their issues, the white students once again had taken the airwaves from the students of color for their own purpose. Both groups were correct. Coalition work is essential to make sure that each group gets access to the airwaves. ${ }^{41}$

A fundanuental tension exists whenever analogies are used to coinpare other oppressions to racism. The coinparison perpetuates racism/ white supremacy, but is also a necessary tool to teach about the oppression being coinpared. Any analogy to race must be used ethically and with care. We inust always consider if we are perpetuating or deconstructing societal racism at the conclusion of any analogy discussion.

\section{EPILOGUE}

Today, the Sunday before Yoin Kippur, I [Stephanie] go with my parents to iny children's Sunday School for the closing service. The Rabbi is explaming to the children the meaning of Yoin Kippur, the hohest Jewish day, the Day of Atonement. "It is the day," he explanis, "when we think of how we could have been better and what we did that wasn't wonderful."

40. Exploration of other -isms would also necessarily be part of such a full discussion. Similarly, in a discussion of racism, one could consider what happens, for example, when middle-class blacks succeed in the white academic world, and are then relied upon to speak for all blacks. Such topics are foreclosed when race and class are discussed as wholly separate but nonetheless fungible, analogous problems.

41. Reagon, Coalition Politics: Turning the Century, in HoMe GiRLs: A Black Feminist ANTHOLOGY 356-68 (B. Smith ed. 1983) (emphasizing both the difficulty of building coalitions and their critical importance). 
He tells a story of two men who came to the Rabbi before Yom Kippur. The first man said he felt very guilty and unclean and could never be cleansed because he had once raised a stick and hurt someone. The second man said he could not think of anything very terrible he had done and that he felt pretty good. The Rabbi told the first man to go to the field and bring back to the synagogue the largest rock that he could find. He told the second man to fill his pockets with pebbles and to bring them back to the synagogue, too.

The first man found a boulder and with much difficulty carried it to the Rabbi. The second man filled his pockets with pebbles, brought them to the Rabbi, and emptied his pockets. Pebbles scattered everywhere.

Then the Rabbi said to the first man, "Now you must carry the rock back and put it back where you found it." To the second man he said, "And you too must gather up all the pebbles and return them to where you found them."

"But how can I do that? That is impossible," said the second man.

The Rabbi telling the story says that the pebbles are like all of the things you have done for which you should wish forgiveness-you have not noticed them, nor kept track.

And so the Rabbi reminds the children that they should consider when they had ever done things that they should not have done.

He then asks them what looks different im the synagogue. The covering of the dais had been changed to white, which he explaims is for purity and cleanliness. He asks the children to stand to see the special torah covers, also white to symbolize atonement and cleanliness.

My mother leans over to me at this point and says, "Can you imagme how someone black feels, hearing a story like this?"

Although no one in the temple was intending to be racist/white supremacist, the conversation could have had that effect, privileging whiteness in a society that is already racist/white supremacist. Is that racism the large rock, the boulder? It must seem truly that large and intractable to people of color. It seeins like a boulder to me, when I think consciously about it. Yet it seems that as whites we treat our own racism like so many little pebbles; part of our privilege is that it may seem unimportant to us. So many times we are racist and do not even realize it, and so cannot acknowledge it nor atone for it, or even attempt to change our behavior. We, like the second man, say we are not racist, because it is our wish not to be. But wishing cannot make it so. The sooner we can see the boulder and the pebbles, the sooner we can try to reinove thein. 